\title{
Univalence conditions and properties of a new general integral operator
}

\section{RoBERTA BuCUR and DANIEL BREAZ}

\section{ABSTRACT.}

In this paper, we obtain univalence conditions and the order of convexity of a new general integral operator defined on the space of normalized analytic functions in the open unit disk $U$. Also, we give some other properties on the class $N(\varphi)$. Results presented in this paper may motivate further reserch in this fascinating field.

\section{REFERENCES}

[1] Alexander, J. W., Functions which maps the interior of the unit circle upon simple regions, Ann. of Math., 17 (1915), 12-22

[2] Becker, J., Lownersche Differential gleichung und quasi-konform fortsetzbare schlichte funktionen, J. Reine Angew. Math., 255 (1972), 23-43

[3] Breaz, D., Certain integral operators on the classes $M\left(\beta_{i}\right)$ and $N\left(\beta_{i}\right)$, J. Inequal. Appl., Vol. 2008, Article ID 719354 (2008), 4 pg.

[4] Breaz, D., Owa, S. and Breaz, N., A new integral univalent operator, Acta Univ. Apulensis Math. Inform., 16 (2008)

[5] Bucur, R., Andrei, L. and Breaz, D., Geometric Properties of a New Integral Operator, Abstr. Appl. Anal., Vol. 2015, Article ID 430197 (2015), 6 pg.

[6] Bucur, R., Andrei, L. and Breaz, D., Univalence criterion, starlikeness and convexity for a new integral operator, Int. Electron. J. Pure Appl. Math., 9 (2015), No. 3, 215-223

[7] Frasin, B. A. and Breaz, D., Univalence conditions of general integral operator, Mat. Vesnik, 65 (2013), No. 3, 394-402

[8] Frasin, B. A. and Jahangiri, J., A new and comprehensive class of analytic functions, An. Univ. Oradea, Fasc. Mat. XV (2008), 59-62

[9] Frasin, B. A. and Darus, M., On certain analytic univalent functions, Int. J. Math. Math. Sci., 25 (2001), No. 5, 305-310

[10] Mayer, O., The functions theory of one variable complex, Bucuresti, 1981

[11] Mocanu, P. T. and Şerb, I., A sharp simple criterion for a subclass of starlike functions, Complex Variables Theory Appl., 32 (1997), No. 2, 161-168

[12] Oprea, A. and Breaz, D., Univalence conditions for two general integral operators, Adv. in Pure Math., 4 (2014), No. 8, 487-493

[13] Owa, S. and Srivastava, H. M., Some generalized convolution properties associated with certain subclasses of analytic functions, J. Inequal. Pure Appl. Math., 3 (2002), No. 3, Art. 42, 1-13

[14] Pascu, N. N. and Pescar, V., On the integral operators of Kim-Merkes and Pfaltzgraff, Stud. Univ. Babeş-Bolyai Math., 32 (1990), No. 2, 185-192

[15] Pescar, V., Some Integral Operators and Their Univalence, J. Anal., 5 (1997), 157-162

[16] Pescar, V., New univalence criteria for some integral operators, Stud. Univ. Babeş-Bolyai Math., 59 (2014), No. 2, $167-176$

[17] Pfaltzgraff, J., Univalence of the integral of $\left(f^{\prime}(z)\right)^{\lambda}$, Bull. Lond. Math. Soc., 7 (1975), No. 3, 254-256

[18] Study, E., Vorlesungen uber ausgewahlte Gegenstande der Geometrie, 2. Heft, Teubner, Leipzig und Berlin, 1913

Received: 23.05.2015; In revised form: 04.03.2016; Accepted: 11.03.2016

2010 Mathematics Subject Classification. 30C45, 30C75.

Key words and phrases. Analytic functions, univalent functions, Starlike functions, convex functions, integral operator, General Schwarz Lemma.

Corresponding author: Roberta Bucur; roberta_bucur@yahoo.com 
[19] Ularu, N. and Breaz, D., Univalence criterion and convexity for an integral operator, Appl. Math. Lett., 25 (2012), 658-661

[20] Ularu, N. and Breaz, D., Univalence condition and properties for two integral operators, Appl. Sci., 15 (2013), 658-661

[21] Uralegaddi, A, Ganigi, M. D. and Sarangi, S. M., Univalent functions with positive coefficients, Tamkang J. Math., 25 (1994), No. 3, 225-230

[22] Wilken, D. R. and Feng, J., A remark on convex and starlike functions, J. Lond. Math. Soc. (2), 21 (1980), No. 2, $287-290$

\section{DEPARTMENT OF MATHEMATics}

UNIVERSITY OF PITEŞTI

StR. TÂRgul Din VALE 1, R-110040 Piteşti, Romania

E-mail address: roberta_bucur@yahoo.com

Department OF MATHEMATICS

"1 DeCEMbrie 1918" University of Alba IUlia

STR. N. IORGA 11-13, R-510009 Alba IUlia, ROMANiA

E-mail address: dbreaz@uab.ro 